\begin{tabular}{|c|c|c|}
\hline \multirow[b]{2}{*}{ FVCF } & $\begin{array}{l}\text { International Journal of Current Research in } \\
\text { Biosciences and Plant Biology }\end{array}$ & \\
\hline & Volume $5 \bullet$ Number 6 (June-2018)・ISSN: 2349-8080 (Online) & \\
\hline $\begin{array}{l}\text { EXCELLENT } \\
\text { PUBLISHERS }\end{array}$ & Journal homepage: www.ijcrbp.com & 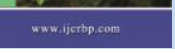 \\
\hline
\end{tabular}

\title{
Bioaccumulation of Heavy Metals by Plants in a Closed Industrial Landfill from Bacau, Romania
}

\author{
Issaka Senou $^{1,2 *}$, Narcis Bârsan ${ }^{3}$, Valentin Nedeff ${ }^{3}$, Hassan B. Nacro ${ }^{4}$ \\ and Antoine N. Somé ${ }^{1}$
}

\begin{abstract}
${ }^{1}$ Laboratory for Natural Systems, Agro-Systems and Environmental Engineering, Institute of Rural Development, Nazi Boni University, BP 1091, Bobo-Dioulasso, Burkina Faso 2Institute of Environmental Sciences and Rural Development, University of Dedougou, Burkina Faso $3^{\prime \prime}$ Vasile Alecsandri” University of Bacau, Department of Environmental Engineering and Mechanical Engineering, 157, Calea Marasesti, 600115, Bacau, Romania

4Fertilization and Research Laboratory on Soil Fertility, Institute of Rural Development, Nazi Boni University, BP 1091, Bobo-Dioulasso, Burkina Faso
\end{abstract}

*Corresponding author.

\begin{tabular}{|c|c|}
\hline Article Info & ABSTRACT \\
\hline $\begin{array}{l}\text { Date of Acceptance: } \\
24 \text { May } 2018\end{array}$ & \multirow{3}{*}{$\begin{array}{l}\text { The heavy metals contents of the soils, the botanical characteristics and the level of } \\
\text { heavy metal accumulation of a closed industrial discharge were examined. The study } \\
\text { should evaluate the levels of heavy metal contamination and accumulative potential of } \\
\text { the site's plants and assess the feasibility of remediation by these plant species. The } \\
\text { results showed high levels of heavy metals }(\mathrm{Cr}, \mathrm{Ni}, \mathrm{Cu}, \mathrm{Zn}, \mathrm{As}, \mathrm{Cd}, \mathrm{Pb}) \text { in the soil. The } \\
\text { botanical study at the dump showed a plant community rich in biodiversity ( } 20 \text { species } \\
\text { and } 6 \text { families), with no obvious toxicity symptoms. Measurements of metal levels in } \\
\text { dominant species confirmed that they were very similar to those reported for species } \\
\text { growing in polluted environments. Metals were found in the leaves and roots of plants } \\
\text { found on the landfill. However, the bioconcentration factors are less than } 1 \text { except for } \\
\text { the case of Carduus australis Pomel in } \mathrm{Zn} \text { which is } 1.04 \text {. Positive correlations were noted } \\
\text { between heavy metal levels in the leaves. Therefore, for effective site restoration, native } \\
\text { species may be well suited to cope with local conditions in a phytoextraction strategy. }\end{array}$} \\
\hline Keywords & \\
\hline & \\
\hline
\end{tabular}

\section{Introduction}

The industrial revolution was the major source of heavy metals into the environment (Alloway, 1995a). The toxicity caused by heavy metals, found in many soils contaminated by industrial activities, constitutes a significant environmental risk for humans. Until recently, industrial waste disposed in large open dumps often extended over several hectares. Today, regulation in most European 
countries does not allow the disposal of waste in open areas and many old landfills have been abandoned. Over time, these landfills have been colonized by a number of plant species, resulting in the gradual formation of the topsoil (Remon et al., 2005), enriched in various heavy metals. Despite the restoration of vegetation cover, these contaminated sites are potential sources of pollution of the local environment; it is therefore necessary to accurately assess their risks and to propose appropriate recovery methods. In this respect, plants could be of great interest both as indicators of the danger of contaminated soils (Fränzle, 2006), and as effective recovery tools (Tordoff et al., 2000; Senou et al., 2018).

In addition to chemical extraction methods, the study of plant communities in terms of species diversity, toxicity, symptoms and metal concentrations in above-ground tissues must be measured to accurately assess phyto-availability and the ecotoxicity of soil metals. In fact, such an approach has already been carried out in a number of potentially hazardous sites, including tailings (Cobb et al., 2000; Stoltz and Greger, 2002), municipal waste (Gimmler et al., 2002) or industrially contaminated (Dudka et al., 1996). Moreover, in addition to understanding the factors governing the vertical transfer of heavy metals, the identification and characterization of plant species capable of growing and surviving in polluted areas could be very useful for developing phytostabilization technologies (Olson and Fletcher, 2000). Indeed, for technical and financial reasons, the removal of metallurgical landfills for disposal at special sites is clearly unrealistic. Therefore, the only way to prevent or minimize the hazards of heavy metals is to control and stabilize existing landfills. In this respect, the restoration of an appropriate vegetation cover (Wong, 2003) could be an effective alternative to the treatment of industrial discharges, which could meet the dual objective of sustainable regeneration of sites and visual improvement of highly degraded areas. However, chemical extraction procedures rarely predict the biological accumulation of metals. The development of complementary methods to evaluate the bioavailability of metals remains necessary. In this perspective, measuring the concentration of metals in the different parts of the selected plants could be an interesting alternative. The polluted soil issue is whether contaminants have an impact on the local ecosystem. In this respect, it is obvious that the study of plant communities living in a polluted environment could be very useful. Indeed, it has long been known that the presence or absence of certain plant species or associations may be a good indicator of edaphic constraints, such as high levels of metals (Brooks, 1983).

In addition to their potential use in bioindication, it is important to have a better understanding of primary plant successions under extreme soil conditions. This should lead to the identification of plant species capable of colonizing heavily polluted soils, which could be used to achieve or accelerate sustainable plant quarrying in ecological restoration strategies (Bradshaw, 1997).

In this article, we have studied the soil and vegetation of an old industrial dump in the city of Bacau (Romania). Our objectives were to evaluate the level of metal contamination of the soils of this landfill and the phytoavailability of heavy metals by the analysis of the vegetation and the accumulative potential of the plants of the site. We have also identified and characterized plant species, which could be used in a phytoextraction strategy for this site.

\section{Materials and methods}

\section{Study site}

The studied industrial discharge $\left(46^{\circ} 31\right.$ '20.04 "N, $26^{\circ} 58^{\prime} 39.79 " \mathrm{E}$ ) was located in the south exit of the city of Bacau (Romania). It was an old industrial dump closed since 2010. The entire landfill covered an area of approximately 46.77 ha. This site, which has shown a well-developed vegetation cover with herbaceous species, has been studied in this work. 


\section{Types of waste and conditions of the discharge}

The landfill was part of the heating network infrastructure of the city of Bacau (Romania). Due to the restructuring of the city heating system, the deposit of slag and ash has been closed. According to HG.349 / 2005 (Municipality of Bacau, Romania, 2015), ash and slag dumps are hazardous industrial waste. The landfill has an area of 46.77 ha with a volume of $3370000 \mathrm{~m}^{3}$ divided into three compartments. The landfill was covered with a 40$60 \mathrm{~cm}$ soil layer and was included in the zonal landscape (Municipality of Bacau, Romania, 2015).

\section{Sampling and soil analysis}

Systematic sampling has been designed (because polluted sites are generally heterogeneous). The study area was divided into three transects (A, B and C) at $10 \mathrm{~m}$ intervals. Soil samples $(0-20 \mathrm{~cm}$ deep) were taken every meter along each transect, yielding 15 sampling points. The samples were dried in the shade for $48 \mathrm{~h}$, screened to $2 \mathrm{~mm}$ and milled to pass a $250 \mu \mathrm{m}$ mesh screen.

The analysis of the metallic trace elements $(\mathrm{Cr}, \mathrm{Ni}$, $\mathrm{Cu}, \mathrm{Zn}, \mathrm{As}, \mathrm{Cd}, \mathrm{Pb}$ ) was carried out by spectrometry with the easyWAVE software or easyCONTROL HPR1000 / 10S high pressure segmented rotor (Milestone ETHOS station, Bacau, Romania). This method allows acid digestion of the sludge sample in a closed cell device using temperature controlled microwave heating for the determination of the metal by spectroscopic methods.

The concentrations of heavy metals in various extracts were measured by inductively coupled optical emission spectrometry (ICP-OES). The wavelengths were chosen by "profile function" to give the greatest sensitivity to each element, without interference. Quantitative analyzes were performed using calibration curves at appropriate concentration levels with PlasmaCal certified single-element standard solutions (SCP Science Canada). All calibration standards were prepared in the same matrix used for the extracts. The detection limits were $0.042 ; 0.124 ; 0.055 ; 1.32 ; 0.035 ; 0.01$; 0.027 respectively for $\mathrm{Cr}, \mathrm{Ni}, \mathrm{Cu}, \mathrm{Zn}, \mathrm{As}, \mathrm{Cd}$ and $\mathrm{Pb}$. To verify the analytical accuracy, randomly selected samples (approximately 20\% of the total number) were measured in triplicate. The relative standard deviation was systematically between 1 and $8 \%$ and never higher than $10 \%$. During the overall sample preparation and analysis process, particular care was taken to minimize contaminants from air, glass and reagents, all of which were analytical grade.

\section{Vegetation study and plant analysis}

Vegetation cover was studied in $1 \mathrm{~m} \times 1 \mathrm{~m}$ quadrants around each of the 15 soil sampling points. Taxa were identified with standard botanical procedures and then named. In each quadrant, the number of individuals of each species and / or the percentage of coverage estimates were recorded. This made it possible to identify the most abundant species.

The accumulation of metals in plant tissues was assessed from the most abundant species. The plant samples were thoroughly washed in tap water and rinsed three times with distilled water. The samples were then separated into leaves, stems and roots, dried at $40^{\circ} \mathrm{C}$ to constant weight. In the metal testing laboratory, the samples were crushed to a 2 $\mathrm{mm}$ sieve. Digestion of the plant samples was performed using $8 \mathrm{ml}$ of $65 \% \mathrm{HNO}_{3}, 0.5 \mathrm{ml}$ of $40 \%$ HF. The concentration of metals in various extracts was measured by ICP-OES as described above.

\section{Statistical analyzes}

The Pearson coefficient is used to evaluate the linear correlation between two metal levels in the leaves and stems of the different species analyzed. Indeed, this type of coefficient makes it possible to establish the existence of a link between 2 variables $\mathrm{X}$ and $\mathrm{Y}$ in order to measure the strength or the intensity of this link. A positive sign indicates that the relationship is proportional, a negative sign that it is inversely proportional. By convention we say that the relation between $\mathrm{X}$ and $\mathrm{Y}$ is perfect if $\mathrm{r}=1$; 
very strong if $r>0.8$; strong if $r$ is between 0.5 and 0.8 ; average if $\mathrm{r}$ is between 0.2 and 0.5 ; low if $\mathrm{r}$ is between 0 and 0.2 and zero if $r=0$. This was calculated using the SYSTAT statistical software (SYSTAT In., Evanston, IL, USA).

\section{Results}

\section{Plant community}

Botanical examination at the dump level yielded 20 species and 6 families (Table 1). Most of these species were herbaceous (18 species) belonging to Asteraceae and Chenopodiaceae. Arthrocnemum fruticosum (L.) Moq. and Chenopodium murale L. were the only shrub species recorded in the study. No trees were noted in the study area. Despite this taxonomic diversity, the vegetation cover was not uniform and, within each quadrant, the area covered, the number of taxa and the type of dominant species were rather variable.

\section{Heavy metal content of soils}

The most obvious feature of the study area was its high level of contamination with various heavy metals (Table 2). This polymetallic pollution was mainly due to $\mathrm{Cr}, \mathrm{Ni}$, As and $\mathrm{Pb}$, whose average concentration values were $56.27 \mathrm{mg} \mathrm{kg}^{-1}, 15.51 \mathrm{mg}$ $\mathrm{kg}^{-1}$ and $17.87 \mathrm{mg} \mathrm{kg}^{-1}$ and 5.95, respectively $\mathrm{mg}$ $\mathrm{kg}^{-1}$, but As has also been detected at relatively high levels (respectively $17.87 \mathrm{mg} \mathrm{kg}^{-1}$ for the mean value). As a general rule, the distribution of heavy metals was homogeneous over the whole surface with the exception of a few points, such as A2, B1 and $\mathrm{C} 3$.

\section{Heavy metal content of plants}

Heavy metal accumulation by vegetation at the site was verified by measuring the metal concentrations in the leaves and roots of the 5 dominant species in various quadrants. The results are shown in Table 3.

In the leaves, the average metal levels were 21.12 $\mathrm{mg} \mathrm{kg}^{-1}$ for $\mathrm{Cr}, 1.86 \mathrm{mg} \mathrm{kg}^{-1}$ for $\mathrm{Ni}, 7.19 \mathrm{mg} \mathrm{kg}^{-1}$ for $\mathrm{Cu}, 20.23 \mathrm{mg} \mathrm{kg}^{-1}$ for $\mathrm{Zn}, 8.65 \mathrm{mg} \mathrm{kg}-1$ for As,
$0.04 \mathrm{mg} \mathrm{kg}^{-1}$ for $\mathrm{Cd}$ and $1.40 \mathrm{mg} \mathrm{kg}^{-1}$ for $\mathrm{Pb}$. In general, root metal concentrations were slightly lower for all metals. On average, they were 19.83 $\mathrm{mg} \mathrm{kg}^{-1}$ for zinc, $8.71 \mathrm{mg} \mathrm{kg}^{-1}$ for copper, $2.44 \mathrm{mg}$ $\mathrm{kg}^{-1}$ for nickel, $2.43 \mathrm{mg} \mathrm{kg}^{-1}$ for $\mathrm{Pb}$, and $0,1 \mathrm{mg} \mathrm{kg}^{-}$ ${ }^{1}$ for $\mathrm{Pb}$. Only $\mathrm{Cr}$ and $\mathrm{As}$ have a high concentration (respectively $28 \mathrm{mg} \mathrm{kg}^{-1}$ for $\mathrm{Cr}$ and $9.16 \mathrm{mg} \mathrm{kg}^{-1}$ for As). However, differences in root and leaf metal levels were not significant (Turkey test, $P>0.05$ for all metals). This indicates that in this plant community, metal concentrations were in equilibrium between roots and leaves. However, our results also suggest that, regardless of the soil metal content, the different plant species present at the site have varying capacities to absorb and accumulate metals. For example, at Carduus australis Pomel., the $\mathrm{Zn}$ contents in the leaves were 2 times higher than in Atriplex halimus L., regardless of the soil metal content. It is the same with Erodium laciniatum (Cav.) Willd. where the levels in the roots are 3 to 4 times higher than in other species.

\section{Bioconcentration factors (concentration in leaves / concentration in soil)}

Bioconcentration factors for heavy metals in leaves (Table 4) are quite heterogeneous regardless of plant species and type of metal. They range from 0.05 (Erodium laciniatum (Cav.) Willd. in Cd) to 1.04 (Carduus australis Pomel. in $\mathrm{Zn}$ ). Bioconcentration factors are generally weak to talk about the accumulation of these metals by the plant species found on the site. Regardless of the plant species, the bioconcentration factors are greater than 0.5 only for $\mathrm{Cu}$ and $\mathrm{Zn}$. However, we can observe a significant heterogeneity between plant species.

\section{Correlations between heavy metal content in the roots and in the leaves of the species}

Correlation coefficients (Pearson correlation) were calculated for each metal combination in leaves and roots (Tables 5, 6).

In the sheets, the correlation coefficient for the $\mathrm{Cd}$ $\mathrm{Zn}$ and $\mathrm{Zn}-\mathrm{Pb}$ pair is very high ( $\mathrm{r}>0.8)$, those for the $\mathrm{Cd}-\mathrm{Pb}$ and $\mathrm{Ni}-\mathrm{Cr}$ pairs are strong $(0.5<\mathrm{r}<08)$. 
The other correlation coefficients between metals are medium or low. In the roots, the correlation coefficient for the Cd-Zn pair is very strong. That of the $\mathrm{Cd}-\mathrm{Pb}$ couple is strong. The other correlation coefficients between metals are medium or low. We found significant differences between correlation coefficients $P<0.01$ and $P<0.05$ in leaves and roots respectively for $\mathrm{Cd}-\mathrm{Zn}$ and $\mathrm{Cd}-\mathrm{Pb}$ pairs. In the roots, a significant difference in correlations is also found for Ni-Cr $(P<0.05)$.

Table 1. List of plants in the study area with their respective families.

\begin{tabular}{|c|c|c|c|c|c|}
\hline Family & Genus & Species & Herbs & Shrubs & Trees \\
\hline \multirow[t]{5}{*}{ Arteraceae } & Astragalus & curaganae Fisch. Mey. & + & & \\
\hline & Carduus & australis Pomel. & + & & \\
\hline & Centaurea & calcitrapa $\mathrm{L}$. & + & & \\
\hline & & sinaica DC. & + & & \\
\hline & Onopordum & palaestinum Eig. & + & & \\
\hline \multirow[t]{2}{*}{ Brassicaeae } & Arthocnemum & fruticosum (L.) Moq. & & + & \\
\hline & Atriplex & halimus L. & + & & \\
\hline \multirow[t]{6}{*}{ Chenopodiaceae } & & stylosa Viv. & + & & \\
\hline & Chenopodium & murale L. & & + & \\
\hline & & vulvaria $\mathrm{L}$. & + & & \\
\hline & Herniaria & glabra L. & + & & \\
\hline & Kochia & indica Wight. & + & & \\
\hline & Salsola & tetrandra Forssk. & + & & \\
\hline \multirow[t]{2}{*}{ Geraniaceae } & Erodium & laciniatum (Cav.) Willd. & + & & \\
\hline & & chium (L.) Willd. & + & & \\
\hline \multirow[t]{2}{*}{ Lamiaceae } & Glecoma & hederacea L. & + & & \\
\hline & Marrubium & vulgare L. & + & & \\
\hline \multirow[t]{3}{*}{ Poaceae } & Bromus & alopecuroides Poir. & + & & \\
\hline & Dactylis & glomerata L. & + & & \\
\hline & Hordeum & glaucum Steud. & + & & \\
\hline
\end{tabular}

Table 2. Heavy metals concentrations $\left(\mathrm{mg} \mathrm{kg}^{-1}\right)$ in the studied soil samples.

\begin{tabular}{cllllllll}
\hline Transect & Sample & $\mathbf{C r}$ & $\mathbf{N i}$ & $\mathbf{C u}$ & $\mathbf{Z n}$ & $\mathbf{A s}$ & $\mathbf{C d}$ & $\mathbf{P b}$ \\
\hline & 1 & 55.19 & 15.54 & 8.41 & 27.11 & 18.27 & 0.12 & 5.95 \\
$\mathbf{4}$ & 2 & 52 & 15.78 & 8.34 & 26.9 & 17.66 & 0.15 & 6.03 \\
& 3 & 58.45 & 15.02 & 9.02 & 27.34 & 18.24 & 0.14 & 6.08 \\
& 4 & 57 & 14.92 & 9.12 & 28.01 & 18.45 & 0.16 & 5.92 \\
& 5 & 48.34 & 14.88 & 8.56 & 26.56 & 17.89 & 0.11 & 5.66 \\
\hline & 1 & 62.12 & 15.8 & 8.97 & 28.12 & 18.36 & 0.90 & 6.04 \\
& 2 & 55.64 & 16.02 & 9.01 & 28.32 & 17.32 & 0.15 & 6.32 \\
& 3 & 51 & 16.12 & 9.34 & 27.54 & 16.99 & 0.17 & 6.55 \\
& 4 & 54 & 15.45 & 8.88 & 28.27 & 16.79 & 0.19 & 5.89 \\
& 5 & 49.54 & 15.77 & 9.12 & 26.66 & 17.87 & 0.20 & 5.26 \\
\hline \multirow{3}{*}{$\mathbf{C}$} & 1 & 61.81 & 16.14 & 9.04 & 27.16 & 18.64 & 0.18 & 4.98 \\
& 2 & 56 & 15.66 & 8.67 & 27.22 & 18.01 & 0.21 & 6.45 \\
& 3 & 63.22 & 15.23 & 8.45 & 26.58 & 18.09 & 0.18 & 6.38 \\
& 4 & 59.33 & 14.99 & 9.04 & 28.30 & 17.6 & 0.20 & 5.56 \\
\hline
\end{tabular}


Table 3. Heavy metal concentrations in leaves and roots from dominant species taken at different points of the study area.

\begin{tabular}{|c|c|c|c|c|c|c|c|c|c|c|c|c|c|c|c|}
\hline \multirow{2}{*}{ Species } & \multirow{2}{*}{ Localization } & \multicolumn{7}{|c|}{ Metal content in leaves $\left(\mathrm{mg} \mathrm{kg}^{-1}\right)$} & \multicolumn{7}{|c|}{ Metal content in roots $\left(\mathrm{mg} \mathrm{kg}{ }^{-1}\right)$} \\
\hline & & $\mathrm{Cr}$ & Ni & $\mathbf{C u}$ & $\mathbf{Z n}$ & As & Cd & $\mathbf{P b}$ & $\mathrm{Cr}$ & $\mathbf{N i}$ & $\mathbf{C u}$ & $\mathbf{Z n}$ & As & Cd & $\mathbf{P b}$ \\
\hline \multirow[t]{4}{*}{ Carduus australis Pomel. } & A 1 & 21.43 & 1.63 & 7.44 & 26.87 & 9.33 & 0.06 & 1.24 & 30.53 & 2.07 & 8.17 & 12.26 & 8.18 & 0.05 & 2.27 \\
\hline & A2 & 22.4 & 1.56 & 7.03 & 28.22 & 8.56 & 0.06 & 1.33 & 31.03 & 2.01 & 7.44 & 11.13 & 10.34 & 0.07 & 2.23 \\
\hline & B1 & 24.01 & 2.02 & 6.83 & 24.77 & 7.77 & 0.06 & 1.29 & 28.54 & 1.99 & 9.34 & 13.47 & 11.03 & 0.08 & 2.09 \\
\hline & $\mathrm{C} 1$ & 19.77 & 1.56 & 6.96 & 25.03 & 11.6 & 0.06 & 1.30 & 34.12 & 2.16 & 6.12 & 9.30 & 6.88 & 0.12 & 2.56 \\
\hline \multirow[t]{3}{*}{ Atriplex halimus L. } & A 1 & 22.33 & 2.35 & 7.10 & 15.61 & 8.41 & 0.04 & 1.04 & 28.16 & 2.66 & 9.21 & 11.41 & 7,75 & 0.05 & 1.73 \\
\hline & B2 & 21.33 & 2.39 & 7.23 & 14.05 & 9.12 & 0.04 & 1.05 & 26.92 & 2.04 & 10.01 & 13.02 & 7.02 & 0.04 & 1.90 \\
\hline & $\mathrm{C} 1$ & 22.12 & 2.44 & 6.24 & 13.66 & 10.44 & 0.04 & 1.67 & 31.14 & 2.38 & 8.38 & 8.90 & 6.30 & 0.03 & 2.01 \\
\hline \multirow[t]{3}{*}{ Erodium laciniatum (Cav.) Willd. } & $\mathrm{C} 3$ & 19.93 & 1.92 & 7.55 & 20.34 & 5.63 & 0.01 & 1.68 & 30,46 & 4.131 & 10.24 & 46.92 & 10.9 & 0.27 & 3.46 \\
\hline & B3 & 20.44 & 1.86 & 7.99 & 21.33 & 7.03 & 0.01 & 1.60 & 27.94 & 3.65 & 11.05 & 38.42 & 11.09 & 0.23 & 3.04 \\
\hline & $\mathrm{C} 2$ & 18.88 & 2.06 & 8.20 & 22.68 & 4.73 & 0.02 & 1.51 & 31.58 & 5.74 & 10.12 & 44.08 & 9.12 & 0.20 & 3.67 \\
\hline \multirow[t]{2}{*}{ Bromus alopecuroides Poir. } & B3 & 23.83 & 1.31 & 7.88 & 19.79 & 9.44 & 0.08 & 1.65 & 25.93 & 1.62 & 7.84 & 17.2 & 9.37 & 0.10 & 2.23 \\
\hline & A 1 & 22.78 & 1.22 & 7.56 & 17.83 & 11.01 & 0.08 & 1.77 & 23.44 & 1.55 & 9.56 & 20.12 & 11.49 & 0.08 & 2.76 \\
\hline \multirow[t]{2}{*}{ Hordeum glaucum Steud. } & A2 & 18.78 & 1.21 & 6.55 & 16.92 & 8.03 & 0.03 & 1.03 & 22.12 & 1.12 & 8.44 & 16.55 & 9.44 & 0.09 & 2.04 \\
\hline & $\mathrm{C} 1$ & 17.07 & 1.13 & 6.15 & 15.65 & 7.09 & 0.04 & 1.45 & 19.89 & 1.08 & 6.02 & 14.91 & 10.07 & 0.11 & 1.99 \\
\hline
\end{tabular}


Table 4. Bioconcentration factors in leaves of different species.

\begin{tabular}{|c|c|c|c|c|c|c|c|c|}
\hline \multirow{2}{*}{ Species } & \multirow{2}{*}{ Localization } & \multicolumn{7}{|c|}{ Bioconcentration factor } \\
\hline & & $\mathrm{Cr}$ & $\mathbf{N i}$ & $\mathbf{C u}$ & $\mathbf{Z n}$ & As & Cd & $\mathbf{P b}$ \\
\hline \multirow[t]{4}{*}{ Carduus australis Pomel. } & A1 & 0.39 & 0.10 & 0.88 & 0.99 & 0.51 & 0.50 & 0.20 \\
\hline & $\mathrm{A} 2$ & 0.43 & 0.10 & 0.84 & 1.04 & 0.48 & 0.40 & 0.22 \\
\hline & B1 & 0.39 & 0.12 & 0.76 & 0.88 & 0.42 & 0.07 & 0.21 \\
\hline & $\mathrm{C} 1$ & 0.31 & 0.09 & 0.76 & 9.92 & 0.62 & 0.33 & 0.26 \\
\hline \multirow[t]{3}{*}{ Atriplex halimus L. } & A1 & 0.40 & 0.15 & 0.84 & 0.57 & 0.46 & 0.33 & 0.17 \\
\hline & B2 & 0.39 & 0.14 & 0.80 & 0.49 & 0.52 & 0.27 & 0.16 \\
\hline & $\mathrm{C} 1$ & 0.36 & 0.15 & 0.69 & 0.50 & 0.56 & 0.22 & 0.33 \\
\hline \multirow{3}{*}{$\begin{array}{l}\text { Erodium laciniatum } \\
\text { (Cav.) Willd. }\end{array}$} & $\mathrm{C} 3$ & 0.40 & 0.12 & 0.89 & 0.76 & 0.31 & 0.05 & 0.33 \\
\hline & B3 & 0.33 & 0.11 & 0.85 & 0.77 & 0.41 & 0.06 & 0.24 \\
\hline & $\mathrm{C} 2$ & 0.31 & 0.13 & 0.94 & 0.83 & 0.26 & 0.09 & 0.23 \\
\hline \multirow{2}{*}{$\begin{array}{l}\text { Bromus alopecuroides } \\
\text { Poir. }\end{array}$} & B3 & 0.46 & 0.08 & 0.84 & 0.71 & 0.55 & 0.47 & 0.25 \\
\hline & $\mathrm{A} 1$ & 0.41 & 0.07 & 0.90 & 0.65 & 0.60 & 0.66 & 0.30 \\
\hline \multirow[t]{2}{*}{ Hordeum glaucum Steud. } & $\mathrm{A} 2$ & 0.36 & 0.07 & 0.78 & 0.62 & 0.45 & 0.20 & 0.17 \\
\hline & $\mathrm{C} 1$ & 0.28 & 0.07 & 0.68 & 0.57 & 0.38 & 0.22 & 0.29 \\
\hline
\end{tabular}

Table 5. Pearson correlations of metal content in leaves of dominants plant species (correlation values $r$ with significant differences marked by a star).

\begin{tabular}{lllllll}
\hline $\mathbf{C r}$ & $\mathbf{N i}$ & $\mathbf{C u}$ & $\mathbf{Z n}$ & $\mathbf{A s}$ & $\mathbf{C d}$ & Leaves \\
\hline 0.054 & 0.015 & -0.003 & 0.937 & 0.004 & $0.658^{*}$ & $\mathbf{P b}$ \\
& $0.524^{*}$ & -0.055 & 0.001 & 0.034 & 0.008 & $\mathbf{C r}$ \\
& & -0.004 & 0.443 & 0.042 & -0.002 & $\mathbf{N i}$ \\
& & 0.002 & 0.011 & 0.002 & $\mathbf{C u}$ \\
& & & 0.034 & $0.962^{* *}$ & $\mathbf{Z n}$ \\
\hline
\end{tabular}

* The correlation is significant at $P<0.05$; ** The correlation is significant at $P<0.01$.

Table 6. Pearson correlations of metal content in roots of dominants plant species (correlation values $r$ with significant differences marked by a star).

\begin{tabular}{lllllll}
\hline $\mathbf{C r}$ & $\mathbf{N i}$ & $\mathbf{C u}$ & $\mathbf{Z n}$ & $\mathbf{A s}$ & $\mathbf{C d}$ & Roots \\
\hline 0.209 & 0.002 & 0.034 & 0.098 & -0.004 & $0.701^{*}$ & $\mathbf{P b}$ \\
& $0.543^{*}$ & -0.012 & -0.014 & 0.002 & 0.006 & $\mathbf{C r}$ \\
& -0.057 & -0.011 & -0.009 & -0.022 & $\mathbf{N i}$ \\
& & 0.002 & 0.025 & 0.001 & $\mathbf{C u}$ \\
& & & -0.009 & $0.884^{* *}$ & $\mathbf{Z n}$ \\
\hline
\end{tabular}

* The correlation is significant at $P<0.05$; ** The correlation is significant at $P<0.01$.

\section{Discussion}

In this study, we analyzed the level of heavy metal contamination and studied native vegetation on an abandoned ash and slag dump. This landfill was part of the heating network infrastructure of the city of Bacau (Romania). Our main objective was to evaluate the phytoavailability of heavy metals by 
analyzing the native vegetation encountered on this landfill.

Our results show that the site has been colonized by a certain number of plant species despite the presence of total heavy metal contents close to or above those generally recognized for polluted soils (Adriano, 2001). The most obvious characteristic of this soil was the presence of heavy metals such as chromium (up to $63.22 \mathrm{mg} \mathrm{kg}^{-1}$ ), nickel (up to $16.14 \mathrm{mg} \mathrm{kg}^{-1}$ ), copper (up to at $9.34 \mathrm{mg} \mathrm{kg}^{-1}$ ), lead (up to $6.45 \mathrm{mg} \mathrm{kg}^{-1}$ ), zinc (up to $28.32 \mathrm{mg} \mathrm{kg}^{-1}$ ), arsenic (up to $17.82 \mathrm{mg} / \mathrm{kg}$ ) $\mathrm{mg} \mathrm{kg}^{-1}$ ) and cadmium (up to $0.9 \mathrm{mg} \mathrm{kg}^{-1}$ ). These concentrations were higher than those measured in unpolluted French natural soils (Baize, 2000), confirming a polymetallic pollution of this landfill. Thus, as a number of authors have already pointed out (Mc Laughlin et al., 2000, Remon et al., 2005), these results on heavy metal contamination of the site indicate that neither total soil "Extractable" concentrations are not enough to accurately assess the fate and effects of contaminants. Therefore, there is now a need to develop complementary methods that could be used to monitor soil quality. In this perspective, the study of plant communities living in a polluted environment (Alvarez et al., 2003; Fränzle, 2006) could have several advantages: they are in close and continuous contact with the polluted substrate, they can accumulate metals in their aerial parts at levels proportional to the available soil content (Baker, 1981), their taxonomy is well established and they can be quickly recognized by a qualified botanist. So far, most studies on the ability of plants to monitor metal pollution have focused on the use of one or a few specific species (Madejon et al., 2004). However, the use of a single species to monitor soil quality has been criticized (Mertens et al., 2005), mainly because the availability of a given metal, and hence its leaf concentration, may be species dependent. Therefore, in this study, we analyzed several species, chosen to be representative of the study sites, in order to obtain a complete picture of the availability of metals for all the plants living on the landfill.
In this study, the metal content was measured in the leaves and roots of plants. The different species studied do not behave in the same way in the face of metallic pollution. The content varies among species but, regardless of species, the maximum accumulation was $24.01 \mathrm{mg} \mathrm{kg}^{-1} \mathrm{Cr}, 2.44 \mathrm{mg} \mathrm{kg}^{-1}$ $\mathrm{Ni}, 2.20 \mathrm{mg} \mathrm{kg}^{-1} \mathrm{Cu}, 28,22 \mathrm{mg} \mathrm{kg}^{-1} \mathrm{Zn}, 11.01 \mathrm{mg}$ $\mathrm{kg}^{-1} \mathrm{As}, 0.8 \mathrm{mg} \mathrm{kg}^{-1} \mathrm{Cd}$ and $1.68 \mathrm{mg} \mathrm{kg}^{-1} \mathrm{~Pb}$ in the leaves. Without roots, the maximum accumulation was $34.12 \mathrm{mg} \mathrm{kg}^{-1} \mathrm{Cr}, 5.74 \mathrm{mg} \mathrm{kg}^{-1} \mathrm{Ni}, 11.05 \mathrm{mg}$ $\mathrm{kg}^{-1} \mathrm{Cu}, 46.92 \mathrm{mg} \mathrm{kg}^{-1} \mathrm{Zn}, 11.01 \mathrm{mg} \mathrm{kg}^{-1}$ As, 0.27 $\mathrm{mg} \mathrm{kg}{ }^{-1} \mathrm{Cd}$ and $3.67 \mathrm{mg} \mathrm{kg}^{-1} \mathrm{~Pb}$. However, a comparison of these values with known baseline levels of micronutrients (Harada and Hatanaka, 2000) in plants growing in the wild indicates that the species of the dump had concentrations quite normal. The low $\mathrm{Pb}$ content could be explained by the low mobility of this metal in soils. The work of Orlowska et al. (2002) showed that lead has low mobility in soil (less mobile than $\mathrm{Zn}$ ). Most of the $\mathrm{Cd}$ or $\mathrm{Pb}$ taken by the plant is stored in the cuticle and cell walls in insoluble form and therefore does not penetrate the plant further (Tremel-Schaub and Feix, 2005). High levels of $\mathrm{Zn}$ and $\mathrm{Cu}$ can be justified by the fact that these metals are trace elements that are naturally taken by plants. However, the process of metal phytoextraction depends on the bioavailability of the metal in the soil (Brown et al., 1995), but this bioavailability can be influenced by multiple factors (abiotic and biotic) in the contaminated environment.

Considering the bioconcentration factors, the dominant species found on the landfill cannot be considered as accumulators of the heavy metals assayed in this study. A species is known as an accumulator if its bioconcentration factor is greater than 1, which means that the concentrations measured in the plant are higher than those in the soil. The strongest factor we measured is for Carduus australis Pomel and is 1.04 for $\mathrm{Zn}$. This result corroborates that of Hammer et al. (2003) for $\mathrm{Zn}$, where the most important bioconcentration factor (1.71) was observed on Salix viminalis clone 78198 on soil containing $1160 \mathrm{mg} \mathrm{Zn} \mathrm{kg} \mathrm{MS}^{-1}$. A positive correlation between $\mathrm{Zn}$ and $\mathrm{Cd}$ concentrations in leaves and roots has been 
demonstrated suggesting a common transport of both metals. $\mathrm{Cd}$ is able to use $\mathrm{Zn}$ transporters, which are present in the plant to absorb the essential element $\mathrm{Zn}$. It has been known for many years that $\mathrm{Zn}$ is a competitor ion of Cd (Hawf and Schmid, 1967) and that it decreases Cd uptake (Mengel and Kirkby, 2001). Cd uptake depends on the amount of $\mathrm{Zn}$ in the soil and plants generally absorb more $\mathrm{Cd}$ if the soil $\mathrm{Zn}$ content is low (Kirkham, 2006).

\section{Conclusion}

Awareness of poor soil health obviously leads to the question of what are the risks to public health and ecosystems in each pollution situation. Indeed, it is widely recognized that natural or anthropogenic sites contaminated by heavy metals can accommodate plant associations strictly subservient to this type of environment, original and singular, sometimes referred to as "metallic groups". The determination of heavy metals in the plants of these sites highlights the degree of transfer of metals and their bioaccessibility for humans.

In the framework of this study, measurements made at the closed industrial discharge site of the city of Bacau (Romania) showed higher or lower metal levels in the soil samples taken. Despite this polymetallic pollution, botanical surveys revealed a floristic diversity, with 20 listed plant species distributed among six botanical families. The analysis of $\mathrm{Cr}, \mathrm{Ni}, \mathrm{Cu}, \mathrm{Zn}, \mathrm{As}, \mathrm{Cd}, \mathrm{Pb}$ content in the leaves and roots of the dominant species showed higher or lower concentrations. However, bioconcentration factors are generally less than 1 .

In order to be able to make the best use of the natural plant species found on the site studied, in phytoremediation programs, it is necessary to clearly characterize the tolerance and accumulation capacity of the dominant species identified on the site with respect to the different toxic elements.

\section{Conflict of interest statement}

Authors declare that there is no conflict of interest.

\section{Acknowledgement}

The authors thank the government of Romania through the "Eugen Ionescu" scholarship. The authors also thank the Department of Environmental Engineering and Mechanical Engineering, Vasile Alecsandri "University of Bacau (Romania) for providing the equipment used to collect the data and sample collection. Milestone Station ETHOS, Bacau (Romania) for the determination of heavy metals.

\section{References}

Adriano, D.C., 2001. Trace elements in terrestrial environments: biogeochemistry, bioavailability and risks of metals. 2nd Springer-Verlag, New York, Berlin, Heidelberg.

Alloway, B.J., 1995. Soil processes and the behaviour of heavy metals. In: Heavy Metals in Soils (Ed.: Alloway, B.J.). Chapman \& Hall, London. pp.11-35.

Alvarez, E., Fernandez Marcos, M.L., Vaamonde, C., Fernandez-Sanjurjo, M.J., 2003. Heavy metals in the dump of an abandoned mine in Galicia (NW Spain) and in the spontaneously occurring vegetation. Sci. Total Environ. 313, 185-197.

Baize, D., 2000. Teneurs totales en "métaux lourds" dans les sols français - Résultats du programme ASPITET. Courrier de l'Environnement de l'INRA 39, 39-54.

Baker, A.J.M., 1981. Accumulators and excluders Strategies in the response of plants to heavy metals. J. Plant Nutr. 3, 643-654.

Bradshaw, A., 1997. Restoration of mined lands using natural processes. Ecol. Eng. 8, 255-269.

Brooks, R.R., 1983. Biological Methods of Prospecting for Minerals. Wiley-Interscience, New York.

Brown, S.L., Chaney, R.L., Angle, J.S., Baker, A.J.M., 1995. Zinc and cadmium uptake by hyperaccumulator Thlaspi caerulescens and metal tolerant Silene vulgaris grown on sludge-amended soils. Environ. Sci. Technol. 29, 1581-1585.

Cobb, G.P., Sands, K., Waters, M., Wixson, B.G., Dorward-King, E., 2000. Accumulation of heavy metals by vegetables grown in mine 
wastes. Environ. Toxicol. Chem. 19, 600-607.

Dudka, S., Piotrowska, M., Terelak, H., 1996. Transfer of cadmium, lead, and Zinc from industrially contaminated soil to crop plants: A field study. Environ. Poll. 94, 181-188.

Fränzle, O., 2006. Complex bioindication and environmental stress assessment. Ecol. Indic. 6, 114-136.

Gimmler, H., Carandang, J., Boots, A., Reisberg, E., Woitke, M., 2002. Heavy metal content and distribution within a woody plant during and after seven years continuous growth on municipal solid waste (MSW) bottom slag rich in heavy metals. J. Appl. Bot. 76, 203-217.

Hammer, D., Kayser, A., Keller, C., 2003. Phytoextraction of $\mathrm{Cd}$ and $\mathrm{Zn}$ with Salix viminalis in field trials. Soil Use Manag. 19, 187-192.

Harada, H., Hatanaka, T., 2000. Natural background levels of trace elements in wild plants: Variation and distribution in plant species. Soil Sci. Plant Nutr. 46, 117-125.

Hawf, L.R., Schmid, W.E., 1967. Uptake and translocation of zinc by intact plants. Plant and hyperaccumulator Thlaspi caerulescens and metal tolerant Silene vulgaris grown on sludge-amended soils. Environ. Sci. Technol. 29, 1581-1585.

Kirkham, M.B., 2006. Cadmium in plants on polluted soils: Effects of soil factors, hyperaccumulation, and amendments. Geoderma. 137, 19-32.

Madejon, P., Maranon, T., Murillo, J.M., Robinson, B., 2004. White poplar (Populus alba) as a biomonitor of trace elements in contaminated riparian forests. Environ. Poll. 132, 145-155.

McLaughlin, M.J., Zarcinas, B.A., Stevens, D.P., Cook, N., 2000. Soil testing for heavy metals. Comm. Soil Sci. Plant Anal. 31, 1661-1700.

Mengel, K., Kirkby, E.A., 2001. Principles of Plant Nutrition, Dorrecht. 849p.

Mertens, J., Luyssaert, S., Verheyen, K., 2005. Use and abuse of trace metal concentrations in plant tissue for biomonitoring and phytoextraction.
Environ. Poll. 138, 1-4.

Municipality of Bacau, Romania, 2015: (http://www.anpm.ro/documents/14011/249730

4/inchidere+depozit+zc+Dana.pdf/44d4ef4bc70d-45b9-9c6a-9ba99ac487ae). (26.08.2016)

Olson, P.E., Fletcher, J.S., 2000. Ecological recovery of vegetation at a former industrial sludge basin and its implications to phytoremediation. Environ. Sci. Poll. Res. 7, 195-204.

Orłowska, E., Zubek, S.Z., Jurkiewicz, A., SzarekŁukaszewska, G., Turnau, K., 2002. Influence of restoration on arbuscular mycorrhiza of Biscutella laevigata L. (Brassicaceae) and Plantago lanceolata L. (Plantaginaceae) from calamine spoil mounds. Mycorrhiza. 12, 153-160.

Remon, E., Bouchardon, J.L., Cornier, B., Guy, B., Leclerc, J.C., Faure, O., 2005. Soil characteristics, heavy metal availability and vegetation recovery at a former metallurgical landfill: Implications in risk assessment and site restoration. Environ. Poll. 137, 316-323.

Senou I., Gnankambary, Z., Some, N.A., Nacro H.B., 2018. Responses of five local plant species to metal exposure under controlled conditions. Int. J. Develop. Res. 8, 1850118506.

Stoltz, E., Greger, M., 2002. Accumulation properties of $\mathrm{As}, \mathrm{Cd}, \mathrm{Cu}, \mathrm{Pb} \mathrm{d} \mathrm{Zn}$ by four wetland plant species growing on submerged mine tailings. Environ. Exp. Bot. 47, 271-280.

Tordoff, G.M., Baker, A.J.M., Willis, A.J., 2000. Current approaches to the revegetation and reclamation of metalliferous mine wastes. Chemosphere. 41, 219-228.

Tremel-Schaub, A., Feix, I., 2005. Contamination des sols. Transfert des sols vers les plantes. ADEME et EDP Sciences (Eds).

Wong, M.H., 2003. Ecological restoration of mine degraded soils, with emphasis on metal contaminated soils. Chemosphere. 50, 775-780.

\section{How to cite this article:}

Senou, I., Bârsan, N., Nedeff, V., Nacro, H. B., Somé, A. N., 2018. Bioaccumulation of heavy metals by plants in a closed industrial landfill from Bacau, Romania. Int. J. Curr. Res. Biosci. Plant Biol. 5(6), 66-75. doi: https://doi.org/10.20546/ijcrbp.2018.506.007 